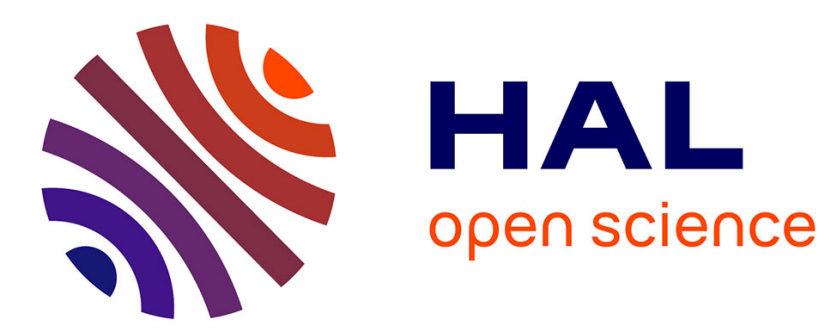

\title{
ON THE MECHANISM OF SILICON NITRIDATION IN THE PRESENCE OF ZrO2
}

K. Rundgren, R. Pompe

\section{To cite this version:}

K. Rundgren, R. Pompe. ON THE MECHANISM OF SILICON NITRIDATION IN THE PRESENCE OF ZrO2. Journal de Physique Colloques, 1986, 47 (C1), pp.C1-515-C1-519. 10.1051/jphyscol:1986177 . jpa-00225608

\section{HAL Id: jpa-00225608 https://hal.science/jpa-00225608}

Submitted on 1 Jan 1986

HAL is a multi-disciplinary open access archive for the deposit and dissemination of scientific research documents, whether they are published or not. The documents may come from teaching and research institutions in France or abroad, or from public or private research centers.
L'archive ouverte pluridisciplinaire HAL, est destinée au dépôt et à la diffusion de documents scientifiques de niveau recherche, publiés ou non, émanant des établissements d'enseignement et de recherche français ou étrangers, des laboratoires publics ou privés. 
JOURNAL DE PHYSIQUE

Colloque $C 1$, supplément au $\mathrm{n}^{\circ} 2$, Tome 47, février 1986

page $\mathrm{C} 1-515$

ON THE MECHANISM OF SILICON NITRIDATION IN THE PRESENCE OF $\mathrm{ZrO}_{2}$

\author{
K. RUNDGREN and R. POMPE* \\ Department of Inorganic Chemistry, Chalmers University of \\ Technology and University of Göteborg, S-412 96 Göteborg, Sweden \\ * The Swedish Institute of Silicate Research, Box 5403, \\ S-402 29 Göteborg, Sweden
}
Résumé- Le présent travail concerne les réactions entre $\mathrm{Si}$ et $\mathrm{ZrO}_{2}$ susceptibles $d^{\top}$ intervenir pendant la nitruration du silicium et pouvant affecter les pro- duits de réaction. Les essais d'analyse thermique, de dilatométrie et de dif- fraction des rayons $\mathrm{X}$ montrent que $\mathrm{Si}$ réagit avec $\mathrm{ZrO}_{2}$ pour donner $\mathrm{ZrSiO}_{4}$ et $\mathrm{ZrSi}_{2-\mathrm{x}}$ :

$$
2 \mathrm{ZrO}_{2}+(3-\mathrm{x}) \mathrm{Si} \longrightarrow \mathrm{ZrSiO}_{4}+\mathrm{ZrSi}_{2-\mathrm{x}}
$$

U1térieurement, la nitruration peut mener à une apparition de $\mathrm{ZrN}, \mathrm{Zr}, \mathrm{O}_{1} \mathrm{~N}_{2}$ et $\mathrm{Si}_{2} \mathrm{~N}_{2} \mathrm{O}$. Certains de ces composés (par ex. $\mathrm{ZrN}$ et $\mathrm{Zr}_{7} \mathrm{O}_{11} \mathrm{~N}_{2}$ ) pourraient diminuer la resistance à $1^{1}$ oxydation du matériau fritté.

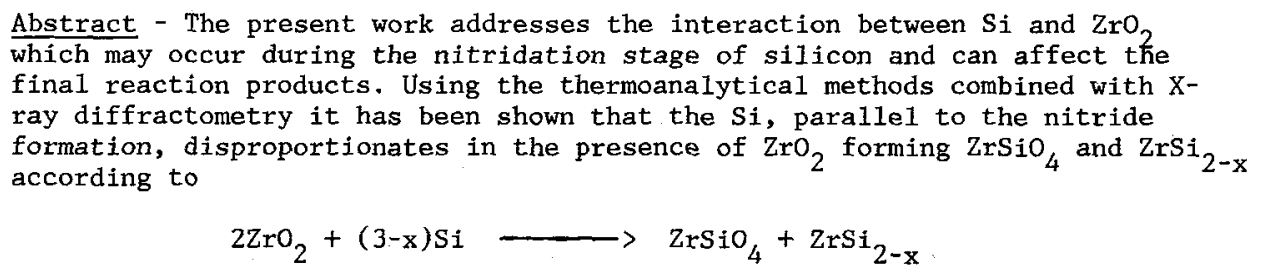

It is shown further that these reaction products form $\mathrm{ZrN}, \mathrm{Zr}_{2} \mathrm{O}_{1} \mathrm{~N}_{2}$ and $\mathrm{Si}_{2} \mathrm{~N}_{2} \mathrm{O}$ during the nitridation. $\mathrm{ZrO}$ thus affects the nitridation so that less desirable by-products are introduced (i.e. $\mathrm{ZrN}, \mathrm{Zr}_{7} \mathrm{O}_{11} \mathrm{~N}_{2}$ ) which may cause a decreased oxidation resistance of the sintered body.

\title{
I - INTRODUCTION
}

Increasing attention has been given in recent years to improving the strength and fracture toughness of ceramics by providing crack arresters in the ceramic matrix. Zirconia systems appear to be the most promising ones to study these phenomena. In partially stabilized zirconia (PSZ) the metastable tetragonal phase will transform to the monoclinic phase in the stress field of propagating cracks. This stress-induced transformation is assumed to provide the principal toughening mechanism in the PSZ. Zirconia is also being considered as a sintering aid for the fabrication of dense $\mathrm{Si}_{3} \mathrm{~N}_{4}$-based ceramics. The emerging techniques (Sintered Reaction Bonded and Nitrided 
Pressureless Sintered Silicon Nitride (SRBSN and NPS-technique))/1,2/ for fabrication of complex shapes of dense $\mathrm{Si}_{3} \mathrm{~N}_{4}$-based ceramics involve use of $\mathrm{Si}$ powder in the starting powder materials. In these new techniques it is of interest to mix the Si powder, before nitridation, with the sintering and/or toughening aids to get dense $\mathrm{Si}_{3} \mathrm{~N}_{4}-$ based ceramics without posttreatments. In this work the interaction between $2 \mathrm{rO}_{2}^{4}$ and $\mathrm{Si}$ has been studied in both $\mathrm{Ar}$ and $\mathrm{N}_{2}$ atmosphere to elucidate the reaction sequence in this system.

\section{II - EXPERIMENTAL METHODS}

The characteristics of the starting powders are given below.

\begin{tabular}{|c|c|c|c|}
\hline & Origin & Impurities (wt. $\%$ ) & BET spec.surface area $\left(\mathrm{m}^{2} / \mathrm{g}\right)$ \\
\hline Si & Kema Nord $A B$ & $0.40 \mathrm{Fe} ; 0.23 \mathrm{Al} ; 0.02 \mathrm{Ca}$ & 2.3 \\
\hline $\mathrm{ZrO}_{2}$ & Kebo Grave: $A B$ & p.a. & 6.5 \\
\hline
\end{tabular}

The powders were mixed in molar ratios $\mathrm{ZrO}_{2}: \mathrm{Si}=1: 2-1: 3$ in an agate mortar and powder compacts then were formed by uniaxial and isostatic pressing. Mettler thermoanalyzer TAI (TGA) and Harrop Dilatometer TD716 (TDA) were used to determine the mass and volumetric change, respectively. The dilatometric (TDA) curves were electronically compensated for the expansion of the alumina holder. The characteristic parameters were as follows: TGA sensitivity/range: $0.05 \mathrm{mg} / 100 \mathrm{mg}$; TDA sensitivity/range: $2 \cdot 10^{-4} \mathrm{~mm}$ per mm rec./1\% per inch; gases used: $\mathrm{N}_{2}-\mathrm{SR}$, Ar-SR (nominal impurity content: less than $15 \mathrm{ppm}$ ); flow rate: ca $5 \mathrm{l} / \mathrm{h}$ The phases were identified by $\mathrm{X}$-ray powder diffractometry (XRD).

\section{III - RESULTS AND DISCUSSION}

1. Dilatcretry, thermogravimetry and XRD.

Fig. 1 shows a dilatometric (TDA) curve for a $\mathrm{ZrO}_{2} / 2.5 \mathrm{Si}$ powder compact in an argon atmosphere. Above about $980{ }^{\circ} \mathrm{C}$ the compact is seen to start shrinking but at $\mathrm{ca} .1200^{\circ} \mathrm{C}$ the shrinkage is altered to expansion which recedes slowly up to $1450{ }^{\circ} \mathrm{C}$. The minimum on the TDA curve coincides with the $m \longrightarrow t-\mathrm{ZrO}_{2}$ phase transition temperature $\left(1175^{\circ} \mathrm{C}\right.$ $/ 3 /)$.

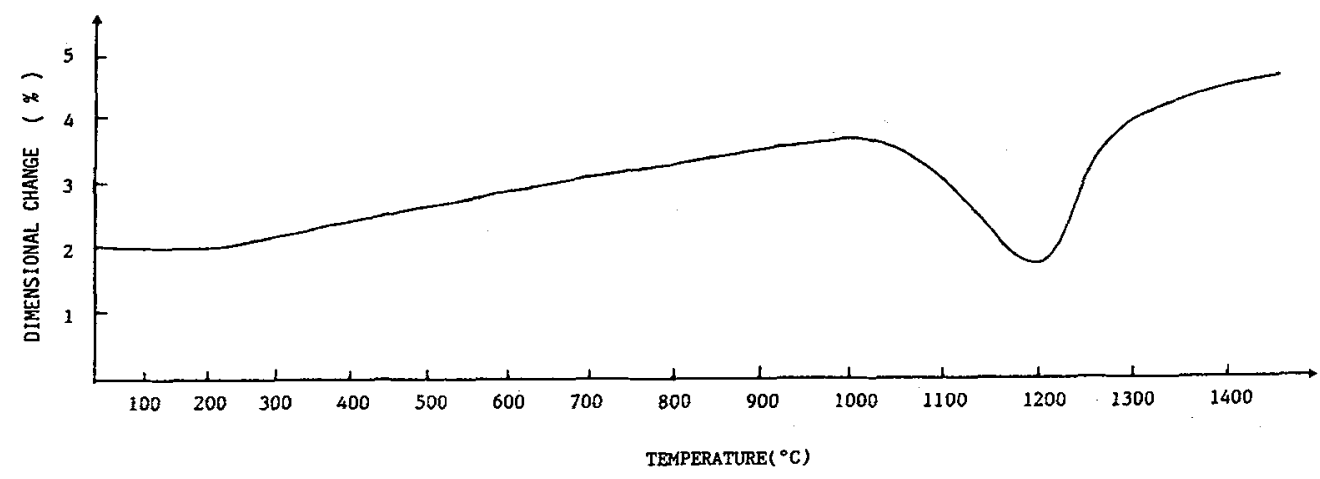

Figure 1. Dilatometric (TDA curve for a $\mathrm{ZrO}_{2} / 2.5 \mathrm{si}$ (molar ratio) powder compact heated at $5 \%$ min in an argon atmosphere. 
As shown in Table' 1 the reaction products obtained at $1450^{\circ} \mathrm{C}$ are $\mathrm{ZrSiO}_{4}$ and $\mathrm{ZrSi}_{2-\mathrm{x}}$, the reaction is however not completed and some unreacted $\mathrm{Si}$ and $\mathrm{ZrO}_{2}$ is always left regardless of the $\mathrm{ZrO}_{2} / \mathrm{Si}$ molar ratio.

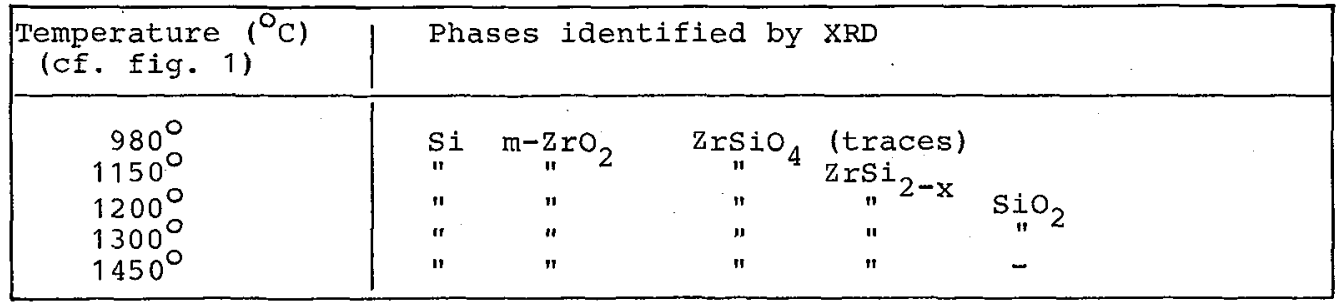

Table 1. Phases identified by XRD for $\mathrm{ZrO}_{2} / \mathrm{Si}$ compacts heated $(5 \% \mathrm{~min}$ ) to different temperatures in Ar atmosphere?

The XRD analysis of the specimens heated at $5 \% /$ min to the temperatures indicated in Table 1 gave the following picture of the reaction processes: At $980^{\circ} \mathrm{C}$ the incipient formation of $\mathrm{ZrSiO}_{4}$ suggests an initial reaction of $\mathrm{ZrO}_{2}$ and the surface silica on the Si particles. The increasing intensities for $\mathrm{ZrSiO}_{4}$ and the appearance of $\mathrm{ZrSi} 2-\mathrm{x}$
at $1150 \mathrm{C}_{\mathrm{C}}$ indicate a reaction proceeding according to

$$
2 \mathrm{~m}-\mathrm{zrO}_{2}+(3-\mathrm{x}) \mathrm{Si} \longrightarrow \mathrm{zrSiO}_{4}+\mathrm{zrSi}_{2-\mathrm{x}} \text {. }
$$

At $1200{ }^{\circ} \mathrm{C}$, which temperature is the turning point of the TDA curve, $\mathrm{SiO}_{2}$ appears as a new phase and the relatively increasing intensity of $\mathrm{ZrSi}_{2-\mathrm{x}}$ at $1300^{\circ} \mathrm{C}$ suggests that the main reaction is

$$
\mathrm{t}-\mathrm{ZrO}_{2}+(3-\mathrm{x}) \mathrm{Si} \longrightarrow \mathrm{ZrSi}_{2-\mathrm{x}}+\mathrm{SiO}_{2} \text {. }
$$

At $1450^{\circ} \mathrm{C}$, however, the $\mathrm{SiO}_{2}$ phase has disappeared and only $\mathrm{ZrSiO}_{4}$ and $\mathrm{ZxSi}_{2-\mathrm{x}}$ remain. TGA indicates a start of weight. loss above $1200^{\circ} \mathrm{C}$. The disappearance of $\mathrm{SiO}_{2}$ is thus probably due to the reaction of $\mathrm{SiO}_{2}$ with residual $\mathrm{Si}$ (and perhaps even $\mathrm{ZrSi}_{2-\mathrm{x}}$ ) giving $\mathrm{SiO}(\mathrm{g})$.

TGA-followed nitridation of the products formed in $\mathrm{Ar}$ at $1450^{\circ} \mathrm{C}$ in $\mathrm{N}_{2}$ gas starts at about $1200^{\circ} \mathrm{C}$ giving $\mathrm{ZrN}, \mathrm{Zr}_{7} \mathrm{O}_{11} \mathrm{~N}_{2}, / 4 /$ and $\mathrm{Si}_{2} \mathrm{~N}_{2} \mathrm{O}$. Direct nitridation of the compacts starts at about $1150^{\circ} \mathrm{C}$ and, in addition to the above products, alpha-Si ${ }_{3} \mathrm{~N}_{4}$ is obtained.

It thus can be concluded that silicon disproportionates in the presence of $\mathrm{ZrO}_{2}$ forming $\mathrm{ZrSiO}_{4}$ and $\mathrm{ZrSi}_{2-\mathrm{x}}$ as final products. The reaction seems to be initiated at a lower temperature or proceeds parallel to the nitridation of $\mathrm{Si}$. The reaction sequence is as shown below.

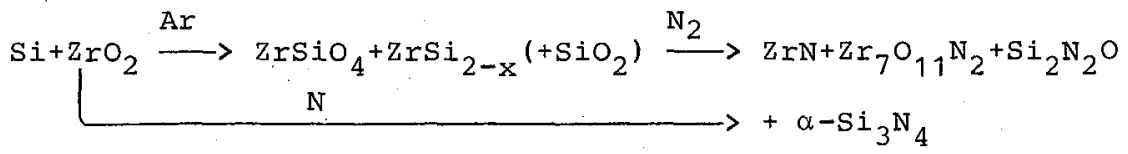

The intermittently released Sio(g) may favour the formation of alpha $-\mathrm{Si}_{3} \mathrm{~N}_{4}$.

\section{Thermodynamical features of the reactions}

2.1 Volumetric changes

As shown in Fig. 1 the TDA curve indicates a change at about $1200^{\circ} \mathrm{C}$ from shrinkage to expansion for the reacting $\mathrm{Si} / \mathrm{ZrO}_{2}$ powder compacts. 
This change coincides with (a) the appearence of $\mathrm{SiO}_{2}$ as an intermediate phase and (b) the $\mathrm{m} \longrightarrow \mathrm{t}-\mathrm{ZrO}_{2}$ phase transition (Teq $1175^{\circ} \mathrm{C}$ ). The chemical equation for the phases formed below $1200^{\circ} \mathrm{C}$ (Table 1) is

$$
2 \mathrm{ZrO}_{2}+(3-\mathrm{x}) \mathrm{Si} \longrightarrow \mathrm{ZrSiO}_{4}+\mathrm{ZrSi}_{2-\mathrm{x}}
$$

and corresponds to a change of molar volume $\Delta \overline{\mathrm{V}} \sim-9.0 \%$ (for $\mathrm{x}=0$ ) and thus is consistent with the observed contraction. Above $1200^{\circ} \mathrm{C}$ formation of $\mathrm{SiO}_{2}$ occurs. The summary equation of

$$
3 \mathrm{ZrO}_{2}+(6-\mathrm{x}) \mathrm{Si} \longrightarrow \mathrm{ZrSiO}_{4}+2 \mathrm{ZrSi}_{2-\mathrm{x}}+\mathrm{SiO}_{2}
$$

leads to $\Delta \overline{\mathrm{V}} \sim-6.4 \%,(\mathrm{x}=0)$ while, instead, an expansion is observed (Fig.1). Considering only the partial process of

$$
t-\mathrm{ZrO}_{2}+(3-\mathrm{x}) \mathrm{Si} \longrightarrow \mathrm{SiO}_{2}(\text { trid. })+\mathrm{ZrSi}_{2-\mathrm{x}}
$$

the $\Delta \bar{V} \sim 0$ for $x=0$ and will change to expansion for $x>0$ unless a significant contraction of the $\mathrm{ZrSi}$ lattice occurs as a result of nonstoichiometry. No such evidence has been apparent from the XR. spectra. The expansion as observed in Fig. 1 above $1200^{\circ} \mathrm{C}$ will certainly be assisted by the transformation of $\mathrm{m}^{-2 \mathrm{rO}_{2}}$ to the $t-\mathrm{ZrO}_{2}$ of lower $\overrightarrow{\mathrm{V}}$. (The above $\bar{v}$ values are based on room temperature data and a significant difference of expansion coefficients for the phases involved may also be of importance in a rigorous treatment).

\subsection{Free enthalpy changes}

Table $\overline{2}$ below shows the thermodynamic data for the total reaction and the partial reaction (2) with the intermediary $\mathrm{SiO}_{2}$ formation.

\begin{tabular}{|r|cc|cc|cc|}
\hline$T(K)$ & $\Delta H(\mathrm{cal} / \mathrm{mol})$ & $\Delta S(\mathrm{cal} / \mathrm{mol} \mathrm{K})$ & \multicolumn{2}{|c|}{$\Delta \mathrm{G}(\mathrm{cal} / \mathrm{mol})$} \\
\hline & $(1)$ & $(2)$ & $(1)$ & $(2)$ & $(1)$ & $(2)$ \\
298 & $1.0 \cdot 10^{3}$ & $7.5 \cdot 10^{3}$ & -0.4 & 0.9 & $1.1 \cdot 10^{3}$ & $7.2 \cdot 10^{3}$ \\
1400 & $-0.9 \cdot 10^{3}$ & $4.1 \cdot 10^{3}$ & -3.2 & -4.1 & $3.6 \cdot 10^{3}$ & $9.8 \cdot 10^{3}$ \\
1600 & $-3.8: 10^{3}$ & $-0.3 \cdot 10^{3}$ & -5.2 & -7.1 & $4.5 \cdot 10^{3}$ & $11.1 \cdot 10^{3}$ \\
\hline
\end{tabular}

Table 2. Thermodynamic data obtained /5/ for reaction (1) and (2).

As is apparent the $\Delta \mathrm{H}$ and $\Delta \mathrm{S}$ value for the total reaction is positive and negative, respectively, over the temperature range of 298-1600 K $\left(25-1327^{\circ} \mathrm{C}\right)$. Thus according to the tabulated data there is no driving force for the reaction (1). For the reaction (2) including the formation of $\mathrm{SiO}_{2}$ the $\Delta \mathrm{H}$ is negative only at $1600 \mathrm{~K}$ but $\Delta \mathrm{S}$ is still negative thus giving positive $\Delta G$ (but much less positive than for the reaction (1)). The reaction (2) however still takes place. To an extent this discrepancy certainly reflects the lack of accuracy in the tabulated data but, at the same time, suggests that the driving force for this reaction is very low. This is consistent with the results of $\mathrm{XRD}$ showing that the reaction is never complete - residual Si and $\mathrm{ZrO}_{2}$ is always present in a relatively significant amount.

Besides, if the reaction (2) gives $\mathrm{zrSi}_{2-\mathrm{x}}$ with $\mathrm{x}>0$ the entropy on the left side will be lower and the entropy on the right side will be increased by a configurational term, due to the non-stoichiometry of $\mathrm{ZrSi}_{2-\mathrm{x}}$. Thus the total $\Delta S$ term may turn positive and give a negative $\Delta G$ already at the temperature of the observed start of the $\mathrm{ZrSi}_{2-\mathrm{x}}$ formation $\left(980^{\circ} \mathrm{C}(1253 \mathrm{~K}), \mathrm{Fig} .1\right)$.

Formation of non-stoichiometric ZrSi $2-x$ is also consistent with the observed expansion above about $1200^{\circ} \mathrm{C}$ (Fig.1). 
IV - CONCLUSION

Pure zirconia reacts with silicon, the reaction being already initiated below $1000^{\circ} \mathrm{C}$. This reaction seems to start at a lower temperature or occurs parallel to the silicon nitride formation. The products formed, $\mathrm{ZrSiO}_{4}$ and $\mathrm{ZrSi}_{2-\mathrm{x}^{\prime}}$ give $\mathrm{ZrN}, \mathrm{Zr}_{7} \mathrm{~N} \mathrm{O}_{2}$ and $\mathrm{Si}_{2} \mathrm{~N}_{2} \mathrm{O}$ as by-products of nitridation. The introduction of these by-products may destroy the oxidation resistance of $\mathrm{Si}_{3} \mathrm{~N}_{4}$ materials sintered with $\mathrm{ZrO}_{2}$.

\section{ACKNOWLEDGEMENT}

Financial support from the Swedish Natural Science Research Council (NFR) is gratefully acknowledged.

\section{REFERENCES}

/1/ Antona, P.I., Giachello, A. and Martinengo, P.C., Ceramic Powders (1983) 753 .

/2/ Pompe, R., Hermansson, I. and Carlsson, R., Brit. Ceram. Soc. 11 (1981) 65 .

/3/ Kubaschewski, $O$. and Alcock, C.B., Metallurgical Thermochemistry, Pergamon Press (1979), 322.

/4/ Gilles, J-C., Buli. Soc. Chim, , (1962), 2118.

15/ Barin, I. and Knacke, O., Thermochemical Properties of Inorganic Substances, Springer-Verlag, (1973). 